\title{
Growth Hormone-Releasing Hexapeptide Is a Potent Stimulator of Growth Hormone Gene Expression and Release in the Growth Hormone-Releasing Hormone-Deprived Infant Rat
}

\author{
VITTORIO LOCATELLI, ROBERTA GRILLI, ANTONIO TORSELLO, \\ SILVANO G. CELLA, WILLIAM B. WEHRENBERG, AND EUGENIO E. MÜLLER \\ Department of Pharmacology, School of Medicine, University of Milan, Milan 20129, Italy \\ [V.L., R.G., A.T., S.G.C., E.E.M.], and Department of Health Sciences and Biological \\ Sciences, University of Wisconsin-Milwaukee, Milwaukee, Wisconsin 53201 (W.B.W.I
}

\section{ABSTRACT}

The growth hormone-releasing hexapeptide (GHRP-6) specifically stimulates growth hormone $(\mathrm{GH})$ secretion in several animal species and humans. The mechanism of action of GHRP-6 is largely unknown, although experimental evidence indicates that it may modulate growth hormone-releasing hormone $(\mathrm{GHRH})$ and somatostatin actions at the pituitary or hypothalamic level. To gain more insight into the mechanism(s) of action of GHRP-6, we studied the infant rat, an animal model highly responsive to GH-releasing stimuli. In 14-d-old rats GHRP-6 (32-600) $\mu \mathrm{g} / \mathrm{kg}$, s.c.) induced a marked and dose-dependent rise in plasma $\mathrm{GH}$ concentrations, maximal stimulation occurring with the dose of $300 \mu \mathrm{g} / \mathrm{kg}$. Neither GHRH nor somatostatin antiserum prevented or modified the $\mathrm{GH}$ release elicited by GHRP-6. In pups passively immunized with GHRH antibodies, a 5-d treatment with GHRP-6 $(80 \mu \mathrm{g} / \mathrm{kg}$, s.c., twice daily) completely counteracted the inhibitory effect of GHRH deprivation on GH mRNA expression. In

GHRP-6 is a synthetic peptide that specifically stimulates growth hormone release in all species so far investigated (1-3). Although GHRP-6 has been shown to stimulate $\mathrm{GH}$ release in vitro from rat primary pituitary cell cultures $(4,5)$, it shows a far greater $\mathrm{GH}$-releasing activity when administered in vivo (6-8). These observations suggest that GHRP-6 stimulates GH secretion by acting

\footnotetext{
Received December 6, 1993; accepted March 4, 1994.

Correspondence: W. B. Wehrenberg, Department of Health Science, University of Wisconsin, P.O. Box 413, Milwaukee, WI 53201.

Reprint requests: Vittorio Locatelli, M.D., Dept. of Pharmacology, University of Milan, via Vanvitelli 32. 20129 Milan, Italy.

Supported by NIH Grants ROIDK.38324 and KO4DK01874.

The present work is part of the program of the "Gruppo per lo studio delle modificazioni della secrezione di ormone somatotropo nelle varie fasi della vita. Approccio fisiopatologico e terapeutico" of the Italian Society of Endocrinology.
}

vitro GHRP-6 $\left(10^{-7}\right.$ and $\left.10^{\circ} \mathrm{M}\right)$ induced a small and transient stimulation of $\mathrm{GH}$ release from cultured pituitary cells. These results indicate the following: 1 ) GHRP- 6 is a potent stimulator of $\mathrm{GH}$ release in rat pups; 2) it stimulates GH gene expression in the GHRH-deprived pup; 3) during the neonatal period its action is not mediated by GHRH or somatostatin; and 4) its actions are not directed at the somatotrophs. (Pediatr Res 36: 169-174, 1994)

\author{
Abbreviations \\ GHRP-6, growth hormone-releasing hexapeptide \\ GH, growth hormone \\ GHRH, growth hormone-releasing hormone \\ GHRH-ab, antiscrum against growth hormone-releasing \\ hormone \\ somatostatin-ab, antiserum against somatostatin \\ NRS, normal rabbit serum
}

on two sites, the pituitary and the hypothalamus. In keeping with these findings, receptor binding sites for GHRP-6 have been demonstrated in both tissues (9). Experimental evidence has indicated that GHRP-6 does not bind to the GHRH receptor (7) or activate adenylate cyclase (4). However, in vivo studies have shown that GHRP-6 potentiates the GH-releasing effect of GHRH when the peptides are coadministered into humans $(8)$ or adult rats (10), and passive immunization against GHRH attenuates the GH response to GHRP-6 (11). Overall, it appears that in vitro results imply independent mechanisms for GHRP-6 and GHRH at the level of the pituitary level $(4,6,8)$, whereas in vivo findings suggest that GHRP-6 may modulate GHRH or somatostatin function at the hypothalamic level (9-11). 
To gain more insight into the mechanism(s) underlying the GH-releasing activity of GHRP-6, we used the infant rat, an animal model well suited for evaluating GHreleasing stimuli (12-14). First, we evaluated the GHreleasing effect of increasing doses of GHRP-6 in vivo. We then tested the GH-releasing effect of GHRP-6 in vitro and compared it to that occurring after GHRH. We then studied the involvement of GHRH and somatostatin in the mechanism of action of GHRP- 6 by the use of passive immunization with specific antisera against GHRH and somatostatin. Finally, we evaluated the capacity of GHRP- 6 to affect pituitary GH gene expression in rats deprived since birth of endogenous GHRH.

\section{METHODS}

\section{Animals}

Male and female 10- and 14-d-old Sprague-Dawley rats (Charles River Breeding Laboratories, Calco, Italy) weighing approximately 25 and $35 \mathrm{~g}$, respectively, were used. They were received on the day of birth and were housed under controlled conditions $\left(22 \pm 2^{\circ} \mathrm{C}, 65 \%\right.$ humidity and artificial light from 0600-2000 h). A standard dry diet and water were available ad libitum to the dams. One hour before the experiments, pups were separated from their respective dam and were randomly divided into groups of eight. All the experiments were performed in accordance with the Italian Guidelines for the Use of Animals in Medical Research.

\section{Antiserum to GHRH and Somatostatin}

The GHRH-ab, prepared and validated by one of us (W.B.W.), has been repeatedly found to inhibit normal GH secretion and slow growth (15-18). In a previous study (16) we evaluated the effect of GHRH-ab (50-200 $\mu \mathrm{L} /$ rat) injected into 10 -d-old rats on $\mathrm{GH}$ secretion. On the basis of that study, a dose of $100 \mu \mathrm{L} /$ rat was chosen because it maximally inhibited GH secretion. The somatostatin-ab was prepared by immunizing rabbits with synthetic somatostatin conjugated to BSA and glutaraldehyde. The antiserum is directed toward the middle part of somatostatin and does not cross-react with other hypothalamic, pituitary, and gastrointestinal peptide hormones. One hundred $\mu \mathrm{L}$ of the undiluted antiserum were able to neutralize approximately $600 \mathrm{ng}$ of somatostatin, an amount that greatly exceeds that present in the 14-dold rat.

\section{Experimental Procedure}

In vivo experiments. In the first series of experiments pups received a single s.c. injection of different doses of GHRP-6 (Bachem, Bubendorf, Switzerland) (i.e. 0, 16, $32,150,300$, and $600 \mu \mathrm{g} / \mathrm{kg}$ dissolved in physiologic saline). Animals were killed by decapitation 20 min later.

In the second experiment, pups received a s.c. injection of $100 \mu \mathrm{L}$ of a GHRH-ab (15) or somatostatin-ab (13) or $100 \mu \mathrm{L}$ of both antiserum (GHRH-ab + somatostatin- ab), or $100 \mu \mathrm{L}$ NRS. One h later they received a s.c. injection of GHRP-6 $(300 \mu \mathrm{g} / \mathrm{kg})$ and were killed by decapitation 20 min after GHRP-6 injection. Trunk blood was collected and immediately centrifuged. Serum samples were stored at $-20^{\circ} \mathrm{C}$ until assayed for GH.

In the third experiment aimed at evaluating the ability of GHRP-6 to stimulate GH synthesis, pups were given GHRH-ab $(100 \mu \mathrm{L} / \mathrm{rat})$ on d 1, 2, 4, 6, 8, and 10 of age. Control-treated rats received an equal volume of NRS. Beginning on $d 6$ or 8 and up to $d 10$, pups were given GHRP-6 $(80 \mu \mathrm{g} / \mathrm{kg}$, s.c., twice daily) or physiologic saline. Twelve $h$ after the last administration of GHRP-6, pups were killed, and the pituitary gland was quickly dissected and frozen on dry ice for the determination of $\mathrm{GH}$ gene expression.

In vitro experiments. Pups were killed by decapitation, and the pituitary glands were rapidly dissected. Pituitary tissue used for cell dissociation included both the anterior and posterior lobes. Briefly, pituitary glands were collected in sterile F-10 medium (Sigma Chemical Co., St. Louis, MO). Tissue was cut into small fragments and incubated twice for $15 \mathrm{~min}$ at $37^{\circ} \mathrm{C}$ in $\mathrm{F}-10$ medium containing 6\% FCS and collagenase $(2.5 \mathrm{mg} / \mathrm{mL})$ (Boehringer, Mannheim $\mathrm{GmBH}$, Germany). Fragments were then washed in Dulbecco's PBS, $\mathrm{Ca}^{2+}$ - and $\mathrm{Mg}^{2+}$-free medium (Sigma Chemical Co.), and mechanically dissociated. Single-cell suspensions were plated onto 24-well $\left(2 \times 10^{5}\right.$ cells/well $)$ culture plates. The cells were incubated in F-10 medium supplemented with $10 \%$ horse serum, $4 \% \mathrm{FCS}$, and gentamycin $(25 \mu \mathrm{g} / \mathrm{mL})$ in a humidified atmosphere of $5 \% \mathrm{CO}_{2}$ and $95 \%$ air at $37^{\circ} \mathrm{C}$. After 3 $\mathrm{d}$, the medium was removed, and the cells were washed twice with serum-free F-10. The cells were then incubated in $1 \mathrm{~mL}$ of F-10 containing $0.1 \%$ BSA with no GH secretagogue or GHRP-6 $\left(10^{-6}, 10^{-7}, 10^{-9} \mathrm{M}\right)$ or GHRH (human GHRH-44, $10^{-8} \mathrm{M}$; Bachem, Philadelphia, PA) or GHRP-6 $10^{-7} \mathrm{M}$ plus GHRH $10^{-8} \mathrm{M}$. Media collected at the end of $15-$ and 30 -min incubations were immediately frozen and stored at $-20^{\circ} \mathrm{C}$ until assayed for $\mathrm{GH}$ content.

\section{Pituitary GH Gene Expression}

Total RNA was isolated by a single-step, acid guanidium thiocyanate-phenol-chloroform extraction method (19). Total RNA samples $(20 \mu \mathrm{g} / \mathrm{sample})$ were run on a $1.2 \%$ formaldehyde agarose gel and transferred to nylon membranes (Hybond N, Amersham, Little Chalfont, UK). The membranes were hybridized with a cDNA probe specific for rat $\mathrm{GH}$ (kindly provided by $\mathrm{F}$. De Noto, University of California, San Francisco, CA). The cDNA probe was labeled by random primer (Megaprime, Amersham) with ${ }^{\circ} \alpha-{ }^{32}$ PédCTP to a specific activity of $1 \times$ $10^{9} \mathrm{dpm} / \mu \mathrm{g}$ DNA. The nylon filters were rehybridized with a ${ }^{\circ} \alpha-{ }^{32}$ PédCTP labeled rat glyceraldehyde 3-phosphate dehydrogenase (G3PDH) probe to control for homogeneity of RNA loading. Autoradiography was carried out at $-70^{\circ} \mathrm{C}$ for $16-24 \mathrm{~h}$ with intensifying screens. Quan- 
tification of hybridization signal was performed on a scanning densitometer (LKB XL, Laser Densitometer, Uppsala, Sweden). Pituitary GH mRNA levels were expressed as percentage of control group values.

\section{GH Assay}

GH concentrations in serum and in the pituitary culture media were measured by RIA with materials kindly provided by the National Institute of Diabetes, Digestive and Kidney Diseases of the National Institutes of Health. Values are expressed in terms of National Institute of Diabetes and Digestive and Kidney Diseases-rat-GHRP-2 standard (potency $2 \mathrm{IU} / \mathrm{mg}$ ) as $\mu \mathrm{g} / \mathrm{L}$ of plasma or medium. The minimum detectable value of rat $\mathrm{GH}$ was $1.0 \mu \mathrm{g} / \mathrm{L}$; intraassay variability was $6 \%$. To avoid interassay variations, we assayed samples from each experiment within one RIA.

\section{Statistical Analysis}

Statistical differences were evaluated by the Dunnett's $\boldsymbol{t}$ test for multiple comparisons, preceded by analysis of variance. A $p$ value less than 0.05 was considered significant.

\section{RESULTS}

Preliminary experiments had indicated that in rat pups serum GH levels peaked $20 \mathrm{~min}$ after the s.c. injection of GHRP-6 (data not shown). Therefore, blood samples from all subsequent studies were collected at that time. Administration of GHRP-6 elicited a marked ( $p<0.05$ ) rise in plasma $\mathrm{GH}$ concentrations at doses of $32,150,300$, and $600 \mu \mathrm{g} / \mathrm{kg}(272,327,456$, and $411 \%$ increase over saline-treated rats, respectively). The dose of $16 \mu \mathrm{g} / \mathrm{kg}$ did not stimulate $\mathrm{GH}$ secretion and that of $300 \mu \mathrm{g} / \mathrm{kg}$ resulted in a maximal response (Fig. 1).

GHRP-6 $\left(10^{-6}\right.$ and $\left.10^{-7} \mathrm{M}\right)$ stimulated $\mathrm{GH}$ release from primary pituitary cell cultures at $15 \mathrm{~min}$ (increase over basal levels, 47 and $37 \%$ for GHRP-6 $10^{-6}$ and $10^{-7} \mathrm{M}$, respectively, $p<0.05$ ); however, such stimulation was not observed at $30 \mathrm{~min}$ of incubation. At both time intervals, GHRP-6 $\left(10^{-9} \mathrm{M}\right)$ failed to stimulate $\mathrm{GH}$ release (Fig. 2). GHRH $\left(10^{-8} \mathrm{M}\right)$ alone or in combination with GHRP-6 $\left(10^{-7} \mathrm{M}\right)$ was effective in stimulating $\mathrm{GH}$ release at 15 (increase over basal levels, 43 and $52 \%$ for GHRH alone and GHRH + GHRP-6, respectively) and $30 \mathrm{~min}$ ( 47 and $52 \%$ for GHRH and GHRH + GHRP-6, respectively) (Fig. 2). The action of the two peptides was neither additive nor synergistic.

In vivo, $1 \mathrm{~h}$ after GHRH-ab administration, basal plasma GH levels were significantly reduced. No significant effect was evident on basal GH levels after treatment with somatostatin-ab or the combination of the two antisera. GH significantly increased in response to GHRP-6 (300 $\mu \mathrm{g} / \mathrm{kg}$, s.c.), and this response was not altered by antiserum pretreatment (Fig. 3).

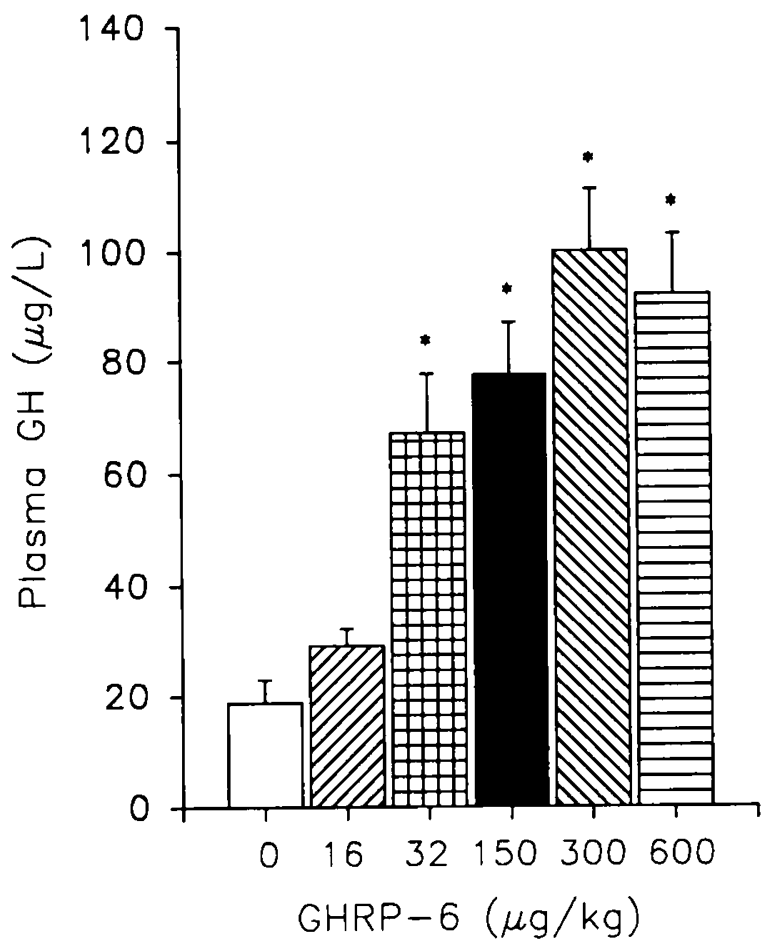

Figure 1. A representative dose-response curve of GHRP-6 on plasma GH concentrations in 14-d-old male and female rats. GHRP-6 $(16,32$, 150,300 , and $600 \mu \mathrm{g} / \mathrm{kg}$ ) or physiologic saline were administered s.c. 20 min before sample collection. Data are the mean \pm SEM of nine replicates for each treatment group. Similar results were obtained in three similar independent experiments. ${ }^{*}, p<0.05$ is vehicle.

Passive immunization of GHRH from d 1 to $d 10$ of age significantly reduced pituitary GH mRNA expression (42\% inhibition versus NRS + saline-treated pups; $p<$ 0.05 ) (Fig. 4). GHRP-6 replacement therapy from d 8-10 of age resulted in only a slight increase in $\mathrm{GH}$ gene expression $(21 \%$ increase versus GHRH-ab + salinetreated pups), but replacement therapy from d 6-10 resulted in full restoration of the GH mRNA expression to control levels $(74 \%$ increase over GHRH-ab + salinetreated rats; $p<0.05)$. GHRP-6 treatment did not stimulate GH mRNA expression in the NRS-treated rats.

\section{DISCUSSION}

GHRP-6 elicited a marked, dose-related rise in plasma $\mathrm{GH}$ in infant rats. Its effects were apparently independent of endogenous GHRH and somatostatin release. Indeed, under our experimental conditions, functional blockade of the hypothalamic control of $\mathrm{GH}$ secretion by passive immunization with specific antisera against GHRH and somatostatin failed to alter GHRP-6-induced GH secretion. In infant rats after short-term GHRH deprivation, the hexapeptide was an effective stimulator of GH gene expression. However, in pituitary cultures GHRP-6 poorly and transiently stimulated $\mathrm{GH}$ release. Thus, we conclude that in infant rats: 1) GHRP-6 is a potent stimulator of $\mathrm{GH}$ release; 2 ) its action occurs primarily at the hypothalamic level; 3) the mode of action of GHRP-6 is independent from the classic neuroendocrine control of 

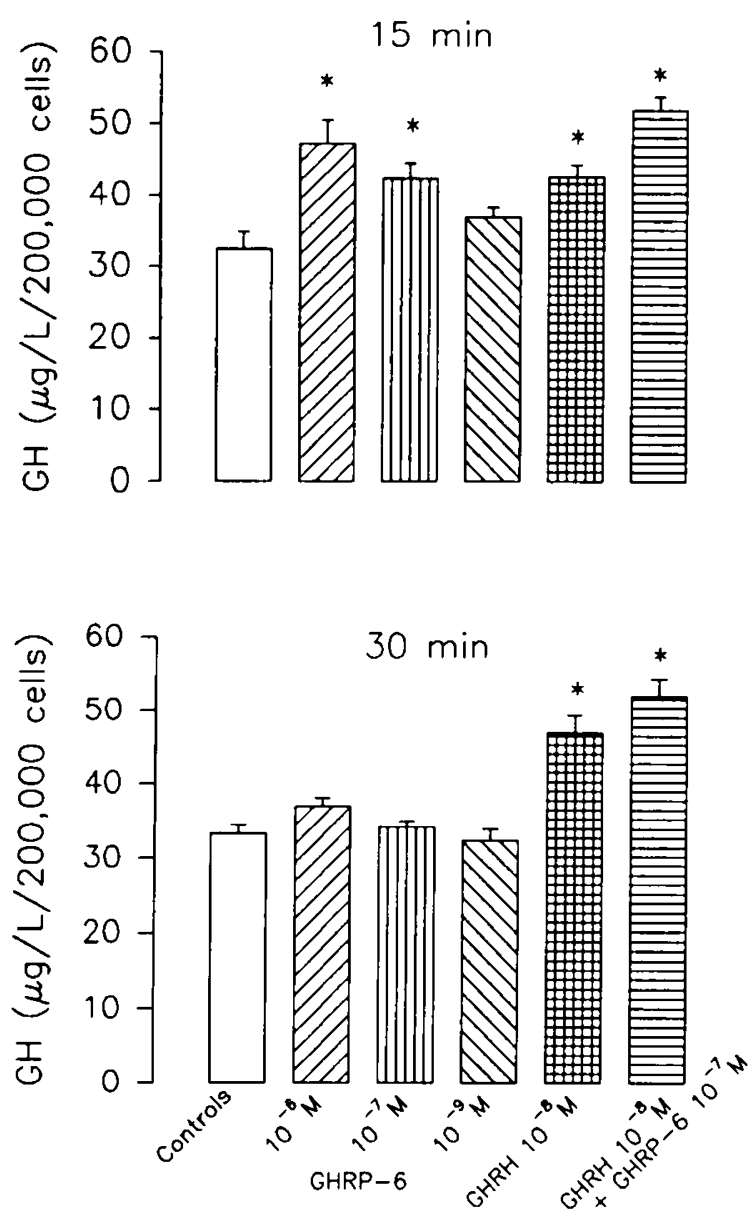

Figure 2. Effect of GHRP-6 and GHRH on GH release from 14-d-old rat pituitary cells. Cells $(200,000$ cells/well $)$ were incubated with GHRP-6 $\left(10^{-8}, 10^{-7}\right.$, and $\left.10^{-6} \mathrm{M}\right)$, GHRH $\left(10^{-8} \mathrm{M}\right)$, GHRP-6 $\left(10^{-7} \mathrm{M}\right)$ $+\operatorname{GHRH}\left(10^{-8} \mathrm{M}\right)$ or medium alone for 15 or $30 \mathrm{~min}$. Values are the mean \pm SEM of six replicates and are representative of the results obtained in three similar independent experiments. ${ }^{*}, p<0.05 v s$ medium alone.

the hypothalamus; and 4) GHRP-6 is a stimulator of GH gene expression in GHRH-deprived rats.

Our data in the infant rat contrast those obtained in adult rats. Clark et al. (11) and Bercu et al. (10) have shown that in the adult rat passive immunization against GHRH produced partial or nearly complete suppression of GHRP-6 activity, indicating that in the adult rat GHRH is a prerequisite for full expression of GHRP-6 activity. In this vein, it has been shown that systemic GHRP-6 administration activates subpopulations of GHRH neurons in the rat arcuate nucleus (20). However, several reports have been presented suggesting that GHRP- 6 and GHRH operate by distinct receptors $(4,6,21,22)$.

Inhibition of endogenous somatostatin activity has also been proposed as a mechanism of GHRP- 6 action in the adult rat (11) and in humans (23). However, in our hands depletion of hypothalamic somatostatin stores by cysteamine (24) did not impair the GH-releasing effect of GHRP-6 in adult rats (25). The reason for the discrepancies between these results and those of the present study may reside in the age of the animals studied. Infant rats,

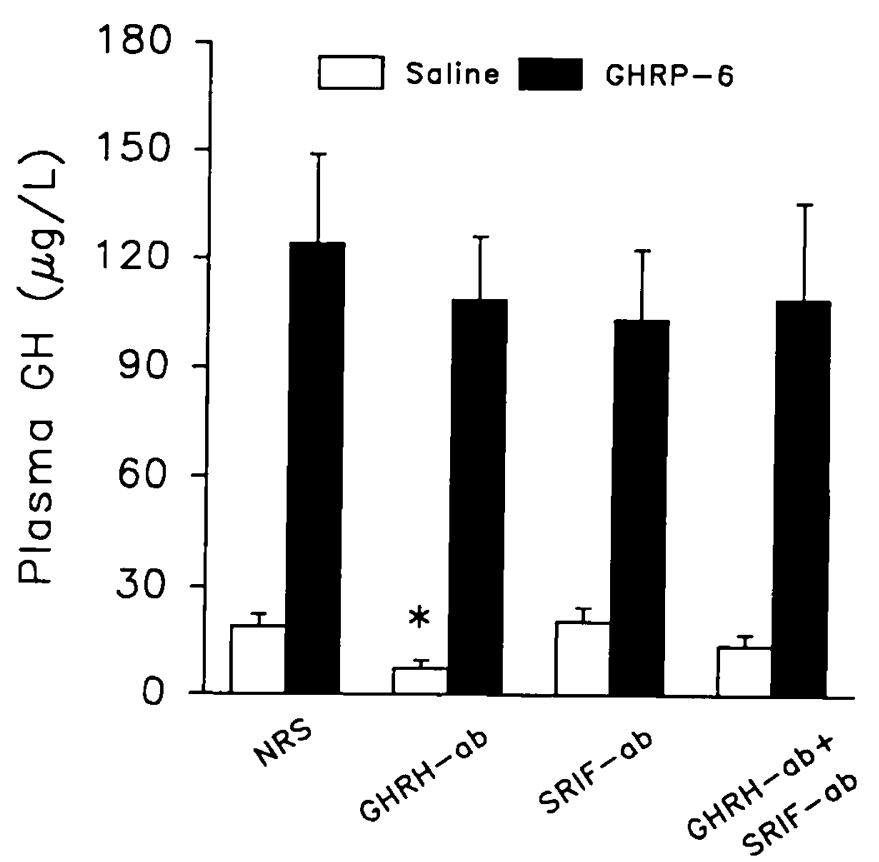

Figure 3. Effect of passive immunization with GHRH-ab and/or somatostatin-ab on GHRP-6 stimulated of GH secretion in 14-d-old rats. Groups of rats were injected with $100 \mu \mathrm{L}$ NRS, $100 \mu \mathrm{L}$ of GHRH-ab or somatostatin-ab, or $100 \mu \mathrm{L}$ GHRH-ab $+100 \mu \mathrm{L}$ somatostatin-ab $1 \mathrm{~h}$ before administration of GHRP-6 $(300 \mu \mathrm{g} / \mathrm{kg}$. s.c.) or physiologic saline. Blood samples were obtained at $20 \mathrm{~min}$ after GHRP-6 administration. Values are the mean \pm SEM of six to eight replicates and are representative of the results obtained in three similar independent experiments. ${ }^{*}, p<0.05$ is NRS-treated rats.

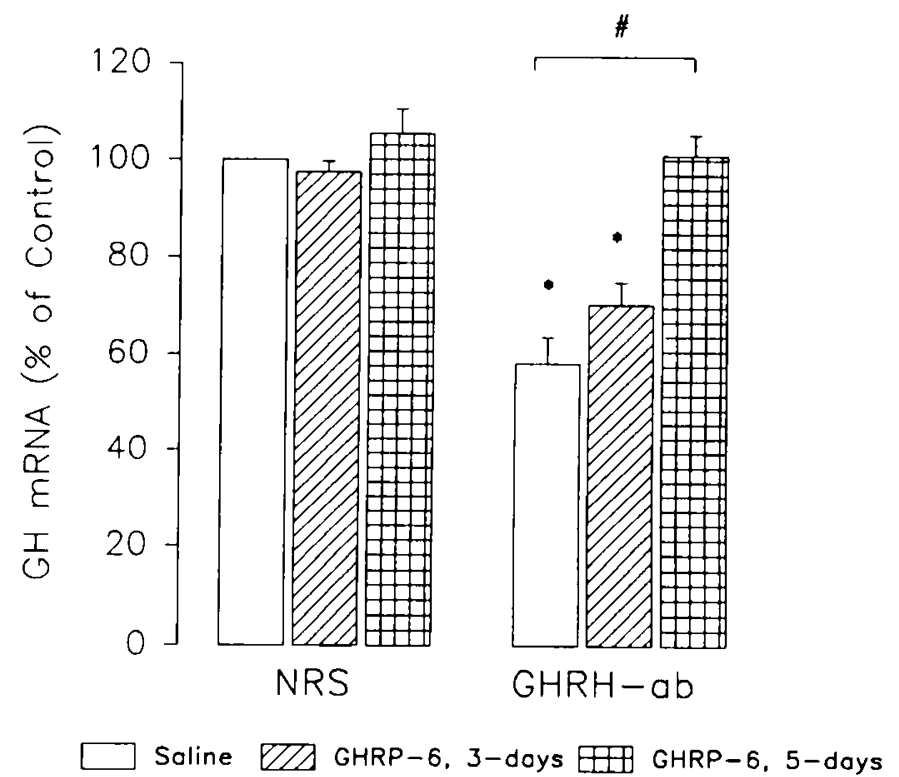

Figure 4. Effect of GHRP-6 on GH gene expression in 10-d-old rat pituitaries. Pups were given NRS or GHRH-ab $(100 \mu \mathrm{L} / \mathrm{rat} / \mathrm{d})$ on d 1, 2, $4,6,8$, and 10 of age. GHRP-6 $(80 \mu \mathrm{g} / \mathrm{kg}$, s.c., twice daily) or physiologic saline was administered from d 8 to $10(3 \mathrm{~d})$ or from $\mathrm{d} 6$ to $10(5 \mathrm{~d})$. Data obtained from two independent similar experiments were evaluated by densitometry, expressed as a percentage of the NRS + saline group and pooled. $n=20-24$ rats for each data point. ${ }^{*}, p<0.05$ vs NRS + saline; \#, $p<0.05$ vs GHRH-ab + saline.

when compared with adult rats, are more sensitive to $\mathrm{GH}$ secretagogues $(12,13,26-28)$ but less sensitive to the inhibitory control of somatostatin (29). 
Proper interpretation of GHRP-6 mechanism of action is further compounded by recent data on GHRP-6 stimulation of GH secretion in rats with surgical ablation of the hypothalamus $(25,30)$ and in hypophysectomized rats bearing ectopic pituitary grafts (30). It is possible that GHRP-6 stimulates GH secretion in vivo through several pathways. For example, stimulation may involve some uncharacterized hypothalamic factor, some specific pituitary receptor, or some unknown peripheral factor. The relative weight of such mechanism(s) in mediating GHRP-6 action in infants rats may be different than in adult rats. It has been shown that stimuli that are ineffective on the adult rat pituitary, such as thyrotropinreleasing hormone, $\gamma$-aminobutyric acid, and galanin are potent $\mathrm{GH}$-releasers in infant rats (26-28). Finally it must be considered that in our study the administration of GHRP-6 stimulated GHRH to such an extent that it overcame the neutralization capacity of the GHRH-ab. Such a hypothesis is unlikely because GHRP-6 was effective even when we doubled the GHRH-ab dose (data not presented).

To the best of our knowledge this is the first report on GHRP-6's ability to stimulate GH mRNA expression. That the hexapeptide is capable of stimulating $\mathrm{GH}$ mRNA expression in GHRH-ab treated rats is intriguing. A 3-d GHRP-6 treatment partially restored GH mRNA expression, and a 5-d treatment completely counteracted the effect of GHRH passive immunization. These data further substantiate the ability of GHRP-6 to stimulate somatotropic function independently from GHRH. However, GHRP-6 administration failed to stimulate $\mathrm{GH}$ gene expression in control pups. Two possible explanations for the latter results are possible. GHRP-6 may be able to stimulate GH mRNA transcription only when the GHRH-dependent GH gene expression is defective. Thus, GHRP-6 stimulation would not be revealed if $\mathrm{GH}$ gene expression is already maximally stimulated under the physiologic influence of GHRH. Alternatively, GHRP-6's ability to stimulate GH gene expression may have been masked in control rats by a concomitant reduction of the GHRH-induced transcription. It is conceivable that GHRP-6-stimulated GH secretion activates autofeedback mechanisms that reduce endogenous GHRH release (31). Regardless of the interpretation offered, the ability of GHRP-6 to take over the function of GHRH when the latter is defective stresses the potential of GHRP- 6 or its analogues $(32,33)$ in the treatment of GHRH-deficient states.

It has been previously reported that GHRP-6 stimulates $\mathrm{GH}$ release from pituitary cells of adult rats in a dose-dependent manner, the maximum effect being achieved at a $10^{-7} \mathrm{M}$ concentration (4). In our in vitro experiments, the stimulatory effect of GHRP-6 on GH release was prompt but of short duration. This indicates that in the neonatal rat the pituitary site of action only marginally contributes to the high $\mathrm{GH}$ response observed in vivo. It may be possible that at this age the GHRP-6 receptor, present in the adult pituitary (9), is not expressed or is functionally immature.

In conclusion, the present study indicates that in infant rats: 1) GHRP-6 is a potent stimulator of GH release; 2) it stimulates GH gene expression in the GHRH-deprived pup; 3) its action is not mediated by GHRH or somatostatin; and 4) its site of action is not on the somatotrophs.

Acknowledgments. The authors thank the National Institute of Diabetes, Digestive and Kidney Diseases of the National Institutes of Health for kindly providing the reagents for the $\mathrm{GH}$ assay.

\section{REFERENCES}

1. Bowers CY, Momany FA, Reynolds GA, Hong A 1984 On the in vitro and in rivo activity of a new synthetic hexapeptide that acts on the pituitary to specifically release growth hormone. Endocrinology 114:1537-1545

2. Baker PK, Conner SD, Doscher ME, Kraft LA, Ricks CA 1984 Use of a synthetic growth hormone releasing hexapeptide to increase rate of weight gain in rats. J Anim Sci 59:220-226

3. Penalva A. Carballo A. Pombo M. Casanueva FF. Dieguez C 1993 Effect of growth hormone $(\mathrm{GH})$-releasing hormone $(\mathrm{GHRH})$, atropine, pyridostigmine. or hypoglycemia on GHRP-6-induced GH secretion in man. J Clin Endocrinol Metab 76:168-171

4. Cheng K, Chan WWS, Barreto A, Convey EM, Smith RG 1989 The synergistic effects of His-d-Trp-Ala-Trp-d-Phe-Lys-NH2 on growth hormone (GH)releasing factor-stimulated $\mathrm{GH}$ release and intracellular adenosine $3^{\prime}, 5^{\prime}$. monophosphate accumulation in rat primary pituitary cell culture. Endocrinology 124:2791-2798

5. Blake AD, Smith RG 1991 Desensitization studies using perifused rat pituitary cells show that growth hormone-releasing hormone and His-D-Trp-Ala-TrpD-Phe-Lys-NH2 stimulate growth hormone release through distinct receptor sites. J Endocrinol 129:11-19

6. Goth MI, Lyons CE, Canny BJ, Thorner MO 1992 Pituitary adenylate cyclase activating polypeptide, growth hormone $(\mathrm{GH})$-releasing peptide and $\mathrm{GH}$ releasing hormone stimulate $\mathrm{GH}$ release through distinct pituitary receptors. Endocrinology 130:939_944

7. Bowers CY, Sartor AO, Reynolds GA, Badger TM 1991 On the actions of the growth hormone-releasing hexapeptide, GHRP. Endocrinology 128:20272035

8. Bowers CY, Reynolds GA, Durham D, Barrera CM, Pezzoli SS, Thorner MO 199) Growth hormone ( $\mathrm{GH}$ )-releasing peptide stimulates $\mathrm{GH}$ release in normal men and acts synergistically with GH-releasing hormone. J Clin Endocrinol Metab 70:975-982

9. Codd EE, Shu AYL, Walker RF 1989 Binding of a growth hormone releasing hexapeptide to specific hypothalamic and pituitary binding sites. Neuropharmacology 28:1139-1144

10. Bercu BB, Yang SW, Masuda R, Walker RF 1992 Role of selected endoge. nous peptides in growth hormone-releasing hexapeptide activity: analysis of growth hormone-releasing hormone, thyroid hormone-releasing hormone, and gonadotropin-releasing hormone. Endocrinology 130:2579-2586

11. Clark RG, Carlsson LMS, Trojnar J, Robinson ICAF 1989 The effects of a growth hormone-releasing peptide and growth hormone-releasing factor in conscious and anaesthetized rats. J Neuroendocrinol 1:249-255

12. Cella SG, Locatelli V, De Gennaro V. Puggioni R, Pintor C, Muller EE 1985 Human pancreatic growth hormone $(\mathrm{GH})$-releasing hormone stimulates $\mathrm{GH}$ synthesis and release in infant rats, an in vivo study. Endocrinology 116:574 577

13. Cella SG, Locatelli V. De Gennaro V, Bondiolotti GP, Pintor C, Loche S. Provezza M, Muller EE 1988 Epinephrine mediates the growth hormonereleasing effect of galanin in infant rats. Endocrinology 122:855-859

14. Cozzi MG, Zanini A, Locatelli V, Cella SG, Muller EE 1986 Growth hormone releasing hormone and clonidine stimulate biosynthesis of growth hormone in neonatal pituitaries. Biochem Biophys Res Commun 138:1223-1230

15. Wehrenberg WB. Bloch B. Phillips BJ 1984 Antibodies to growth hormonereleasing factor inhibit somatic growth. Endocrinology 115:121 -1220

16. Cella SG, Locatelli V. De Gennaro V, Wehrenberg WB, Muller EE 1987 Pharmacological manipulations of alpha-adrenoceptors in the infant rat and effects on growth hormone secretion. Study of the underlying mechanisms of action. Endocrinology 120:16.39-164.3

17. Cella SG, Locatelli V, Mennini T, Zanini A, Bendotti C. Forloni GL. Fumagalli G, Arce VM, de Gennaro Colonna V, Wehrenberg WB, Muller EE 199() Deprivation of growth hormone-releasing hormone early in the rats neonatal life permanently affects somatotropic function. Endocrinology 127:1625-1634

18. Wehrenberg WB, Voltz DM, Cella SG, Muller EE, Gaillard RC 1992 Longterm failure of compensatory growth in rats following acute neonatal passive immunization against growth hormone-releasing hormone. Neuroendocrinology $56: 509-515$ 
19. Chomczynski P, Sacchi A 1987 Single-step method of RNA isolation by acid guanidinum-thiocyanate-phenol-chloroform extraction. Anal Biochem 162:156-159

20. Dikson SI, Leng G, Robinson ICAF 1993 Systemic administration of growth hormone-releasing peptide activates hypothalamic arcuate neurons. Neuroscience 53:303-306

21. Debell WK, Pezzoli SS, Thorner MO 1991 Growth hormone (GH) secretion during continuous infusion of GH-releasing peptide: partial response attenuation. J Clin Endocrinol Metab 72:1312-1316

22. Smith RG, Cheng K, Schoen WR, Pong SS, Hickey G, Jacks T, Butler B, Chan WWS, Chaung LYP, Judith F, Taylor J, Wyvratt MJ, Fisher MH 1993 A nonpeptidyl growth hormone secretagogue. Science 260:1640-1643

23. Bowers CY $1993 \mathrm{GH}$ releasing peptides: structure and kinetics. J Pediatr Endocrinol 6:21-31

24. Szabo S, Reichlin S 1981 Somatostatin in rat tissues is depleted by cysteamine administration. Endocrinology 109:2255-2257

25. Cananzi MM, Torsello A, Cella SG, Deghengi R, Locatelli V 1992 Hypophysiotropic action of GHRP-6 on growth hormone release in the rat. J Endocrinol Invest 15(suppl 1-4):23

26. Welsh JB, Cuttler L, Szabo M 1986 Ontogeny of the in vitro growth hormone stimulatory effect of thyrotropin-releasing hormone in the rat. Endocrinology 119:2368-2375
27. Acs Z, Szabo B, Kapocs G, Makara GB 1987 Gamma-aminobutyric acid stimulates pituitary growth hormone secretion in the neonatal rat. A superfusion study. Endocrinology 120:1790-1798

28. Torsello A, Sellan R, Cella SG, Locatelli V, Muller EE 1990 Age-dependen modulation by galanin of growth hormone release from rat pituitary cells in culture. Life Sci 47:1861-1866

29. Rieutort M 1981 Ontogenetic development of the inhibition of growth hormone release by somatostatin in the rat: in vivo and in vitro (perfusion) study. $\mathrm{J}$ Endocrinol 89:355-363

30. Mallo F, Alvarez CV, Benitez L, Burguera B, Coya R, Casanueva FF, Dieguez C 1993 Regulation of His-dTrp-Ala-Trp-dPhe-Lys-NH2 (GHRP-6)induced GH secretion in the rat. Neuroendocrinology 57:247-256

31. Cella SG, de Gennaro Colonna V, Locatelli V, Moiraghi V, Loche S, Wehrenberg WB, Muller EE 1990 Growth hormone $(\mathrm{GH})$ autofeedback action in the neonatal rat: involvement of GH-releasing hormone and somatostatin. J Endocrinol 124:199-205

32. Deghenghi R, Cananzi MM, Battisti CTA, Locatelli V, Muller EE 1992 Hexarelin (EP23905): a superactive growth hormone releasing peptide. J Endocrinol Invest 2(suppl 4):45

33. Wehrenberg WB, Giustina A, Imbimbo B, Stagg L, Conley LK, Deghenghi R 1992 Biological potency of hexarelin (EP23905), a new potent growth hormone-releasing peptide. J Endocrinol Invest 2(suppl 4):45 